\section{AB0003 A GALNT3 GENE MUTATION IN TWO SIBS WITH CHRONIC RECURRENT MULTIFOCAL OSTEOMYELITIS ASSOCIATED WITH HYPERPHOSPHATEMIC FAMILIAL TUMORAL CALCINOSIS}

D. El Dessouki ${ }^{1}$, M.S. Abdel-Hamid ${ }^{2}$, M.I. Mehrez ${ }^{3}$, M.S. Aglan ${ }^{1}$, S.A. Temtamy ${ }^{1}$ ${ }^{1}$ Clinical Genetics; ${ }^{2}$ Medical Molecular Genetics; ${ }^{3}$ Oro-dental Genetics, National Research Centre, Giza, Egypt

Background: Chronic recurrent multifocal osteomyelitis (CRMO) is an uncommon inflammatory disease mostly affects the metaphyses of long bones. It can be distinguished from osteomyelitis by multifocality and recurrence. Hyperphosphatemic familial tumoral calcinosis (HFTC) is a rare genetic disorder characterised by increased re-absorption of phosphate through the renal proximal tubule leading to increased phosphate concentration and deposition of calcified deposits in cutaneous and subcutaneous tissues, as well as some visceral organs. HFTC is inherited in an autosomal recessive manner and is caused by mutations in three different genes, FGF23, GALNT3 and KLOTHO. CRMO has been associated with some chronic inflammatory diseases such as inflammatory bowel disease, palmoplantar pustulosis and SAPHO syndrome. The association of CRMO and HFTC is extremely rare and only three patients have been described so far in the literature. Objectives: To report the clinical, radiological and molecular findings of two sibs with CRMO associated with HFTC.

Methods: In this report, we present two siblings; offspring of consanguineous parents. They presented with spontaneous bony pains not responding to NSAID and later on, that developed tender hard masses. There were no similarly affected family members, and they had a non-affected sibling. Clinical, laboratory, pathological and radiological examination was performed. Mutational analyses of the FGF23, GALNT3 and KLOTHO genes was carried out by Sanger sequencing of the entire coding region of each gene.

Results: Laboratory results including blood cultures and sensitivities were normal, apart from mildly elevated ESR. Serum calcium, $25(\mathrm{OH})$ vitamin D, renal functions, albumin, alkaline phosphatase, parathormone hormone, and phosphorous were normal apart from hyperphoshatemia in both siblings.

Initial $x$-rays revealed lytic lesions with a sclerotic margin. Follow up $x$-rays showed healing with sclerosis and hyperostosis. After developing the hard masses, x-rays showed calcified masses. Resection pathological analysis revealed non-neoplastic inflammatory bone growth with prominent periosteal and bone proliferation, it was free from any granulomatous or malignant changes. We suggested a provisional diagnosis of CRMO associated with HFTC. Molecular studies confirmed the diagnosis by identifying a known pathogenic mutation in the donor splice site of exon 8 of the GALNT3 gene, c.1524+1G>A. The mutation was found in the homozygous form in the two sibs and both parents were heterozygous.

Conclusions: This study documents the first Egyptian family clinically diagnosed with CRMO associated with HFTC and confirmed by molecular studies, with the identification of a splice mutation in the GALNT3 gene.

Acknowledgements: This work was funded by the STDF grant number 5253.

Disclosure of Interest: None declared

DOI: 10.1136/annrheumdis-2018-eular.2975

\section{AB0004 PHARMACOGENETIC ASPECT OF METOTREXATE, IN A GROUP OF COLOMBIAN PATIENTS WITH RHEUMATOID ARTHRITIS}

E.L. Saldarriaga ${ }^{1}$, C.A. González ${ }^{1}$, L.F. Restrepo ${ }^{1}$, R. Giraldo-Bustos ${ }^{1}$, J. G. Ballesteros-Muñoz ${ }^{1}$, A.Y. Vásquez ${ }^{1}$, S. Arias-Correal ${ }^{1}$, L. Valero ${ }^{1},{ }^{1}$ M. J. Ospina ${ }^{1}$, P. Lopez-Morales ${ }^{1}$, E. Couto-Luvie ${ }^{1}$, M.J. Soares-Santeugini ${ }^{1}$, J.I. Angarita ${ }^{1}$, J.C. Rueda ${ }^{1}$, F.-M. Cuervo ${ }^{1}$, P. Santos-Moreno ${ }^{2}$, J. Londoño ${ }^{1}$, A. M. Santos ${ }^{1}{ }^{1}{ }^{1}$. Department of Rheumatology and Immunology - Group of spondyloarthropathies, Universidad de la Sabana; ${ }^{2}$ BIOMAB, Centro de Artritis Reumatoide, bogota, Colombia

Background: Methotrexate (MTX) as monotherapy or in combination, is the most commonly Disease-Modifying-AntiRheumatic-Drug (DMARDs) used in rheumatoid arthritis (RA). About $40 \%$ of patients do not respond to treatment or have adverse effects. The genetic variability could be responsible for this phenomenon. Different studies suggest associations between polymorphisms in the enzymes involved in the metabolic pathway of MTX with alterations in the efficacy and toxicity.

Objectives: Determine the polymorphisms of the enzymes involved in MTX metabolism in a group of Colombian patients.

Methods: 400 patients with RA over 18 years old, diagnosed according to the ACR/EULAR classification criteria, who consecutively attended an outpatient RA clinic between March 2015 and December 2016 were included. MTX efficacy was defined by DAS28 score $\geq 3.2$, liver toxicity by elevation of transaminases above three times the normal value, Haematological toxicity by: leukocytes $<4,000, \mathrm{Hb}$ $<9.5$, platelets $<150,000$, renal toxicity: creatinine $>1.5$. The single nucleotide polymorphisms (SNPs) studied were MTHFR C677T, MTHFR A1298C, ATIC C347G,
RFC1 G80A, FPGS-AG and DHFR-CT and were identified by the technique of polymerase chain reaction in real time (RT-PCR).

Results: The mean age of patients was $60.7 \pm 13.9$ years, the duration of the disease was $13.2 \pm 10.9$ years and $76 \%$ were women. A significant increase in the frequency of MTHFR C677T and A1298C SNPs ( $p=0.05$ and $p=0.048$ ) were found in the responding patients compared to non-responders. The DHFR-CT and the ATIC C347G SNPs were significantly increased in patients with any toxicity to MTX ( $p=0.0095$ and $p=0.005$ respectively). We did not find a significant difference between the polymorphisms studied with any specific toxicity.

\begin{tabular}{|c|c|c|c|c|c|}
\hline Polymorphisms & $\mathbf{n}$ & $\begin{array}{c}\text { Activity } \\
(\%)\end{array}$ & $\begin{array}{c}\text { Remission } \\
(\%)\end{array}$ & OR-95\%(IC) & $p$ \\
\hline MTHFR C677CC & 344 & 189 & 155 & \multirow[t]{3}{*}{$1.62(1.0-2.68)$} & \multirow[t]{3}{*}{0.05} \\
\hline $\mathrm{CC}$ & 81 & $37(20)$ & $44(28)$ & & \\
\hline TT & 263 & $152(80)$ & $111(72)$ & & \\
\hline MTHFR A1298 & 381 & 219 & 162 & \multirow{3}{*}{$\begin{array}{c}1.74(1.01- \\
3.02)\end{array}$} & \multirow[t]{3}{*}{0.048} \\
\hline AA & 312 & $172(79)$ & $140(86)$ & & \\
\hline TT & 69 & $47(21)$ & $22(14)$ & & \\
\hline DHFR & 394 & 225 & 165 & \multirow{4}{*}{$\begin{array}{c}1.03(0-68- \\
1.55)\end{array}$} & \multirow[t]{4}{*}{0.484} \\
\hline $\mathrm{CC}$ & 233 & $131(58.2)$ & $95(57.6)$ & & \\
\hline TT & (58.3) & $91(40.5)$ & $68(41.2)$ & & \\
\hline & $\begin{array}{c}161 \\
(25.8)\end{array}$ & & & & \\
\hline FPGS & 400 & 225 & 165 & \multirow{5}{*}{$\begin{array}{c}1.92(0.69- \\
1.41)\end{array}$} & \multirow[t]{5}{*}{0.406} \\
\hline AA & 137 & $74(32.9)$ & 57 (34.5) & & \\
\hline \multirow[t]{3}{*}{ GG } & (34.3) & $151(67.7)$ & $108(65.5)$ & & \\
\hline & 263 & & & & \\
\hline & $(65.7)$ & & & & \\
\hline
\end{tabular}

Abstract AB0004 - Table 2

\begin{tabular}{|c|c|c|c|c|}
\hline Polvmorphisms. & $\mathrm{n}$ & Taxicity & OR-95\%(IC) & p \\
\hline $\begin{array}{c}\text { MTHFR C677CC } \\
\text { CC } \\
\text { TT }\end{array}$ & $\begin{array}{c}316 \\
74 \\
242\end{array}$ & $\begin{array}{l}81 \\
22 \\
59\end{array}$ & $1.31(0.73-2.34)$ & 0.21 \\
\hline $\begin{array}{c}\text { MTHFR A1298 } \\
\text { AA } \\
\text { TT }\end{array}$ & $\begin{array}{c}312 \\
261 \\
51\end{array}$ & $\begin{array}{l}80 \\
70 \\
10\end{array}$ & $1.50(0.71-3.16)$ & 0.184 \\
\hline $\begin{array}{l}\text { DHFR } \\
\text { CC } \\
\text { TT }\end{array}$ & $\begin{array}{l}313 \\
175 \\
136\end{array}$ & $\begin{array}{l}81 \\
55 \\
26\end{array}$ & $1.93(1.13-3.30)$ & 0.0095 \\
\hline $\begin{array}{c}\text { ATIC C347 } \\
\text { CC } \\
\text { GG }\end{array}$ & $\begin{array}{l}313 \\
121 \\
192\end{array}$ & $\begin{array}{l}80 \\
41 \\
39\end{array}$ & $2(1.2012-3.36)$ & 0.005 \\
\hline
\end{tabular}

Conclusions: The Colombian population has similar statistical data compared to the global studies regarding the association of SPNs with the efficacy and toxicity of methotrexate, however the polymorphisms associated with inefficiency in the literature are not replicated in our data. These SNPs could be established as biomarkers to the methotrexate response in terms of efficacy and toxicity in our Colombian population with RA.

\section{REFERENCE:}

[1] Fan H, Li Y, Zhang L, Li W. Lack of association between MTHFR A1298C polymorphism and outcome of methotrexate treatment in rheumatoid arthritis patients: Evidence from a systematic review and meta-analysis. Int J Rheum Dis 2017;20(5):526-40

Disclosure of Interest: None declared DOI: 10.1136/annrheumdis-2018-eular.2046

\section{AB0005 HLA CLASS II IN PARAGUAYAN IMMUNE-MEDIATED INFLAMMATORY PATIENTS}

I. Acosta-Colman ${ }^{1}$, S. Cabrera-Villalba ${ }^{1}$, G. Avila-Pedretti ${ }^{1}$, M.E. Acosta Hetter ${ }^{2}$, M. Vazquez ${ }^{1}$, A. Ayala Lugo ${ }^{2}, V_{\text {. Jolie }}^{2}$, L. Roman ${ }^{1}$, M. Melo', M. González ${ }^{1}$, M. Duarte ${ }^{1}$, H. Torio ${ }^{3}$, M.T. Martínez de Filártiga ${ }^{3}{ }^{1}$ Departamento de Reumatologia, Hospital de Clinicas de la Facultad de Medicina de la Universidad Nacional de Asunción; ${ }^{2}$ Instituto de Investigación en Ciencias de la Salud; ${ }^{3}$ Laboratorio Curie, Asunción, Paraguay

Background: Immune-mediated inflammatory disease (IMID) is a concept used to describe a group of conditions that share common inflammatory pathways leading to systemic inflammation. The best-known genetic factor for IMID susceptibility is the human leukocyte antigen (HLA) haplotypes. Nowadays, there is a lack of information about HLA profile in Paraguayan patients with IMIDs. 